\title{
Profiling the life course of resource-based boomtowns: A key step in crime prevention
}

\author{
Rick Ruddell* and Heather A. Ray ${ }^{\dagger}$
}

The rapid population growth and industrialization associated with a natural resource-based boom poses a number of challenges for the residents of a small community, including significant reductions in their quality of life, well-being, and public safety. The majority of Canadian communities undergoing such growth are associated with the extraction of oil and gas or other mining operations, although booms do also occur in single-industry towns (Broadway, 2007). Since 2000 dozens of boomtowns have emerged throughout Canada, from Kitimat, British Columbia to St. John's, Newfoundland. With the exception of Fort McMurray, Alberta, however, very few of these places receive much attention as they are often small towns in rural and remote places that are both out of sight and out of mind. The challenges created by rapid population growth, however, are of critical importance to the residents, as well as the workers in the health, education, social service, and justice systems who must respond to escalating demands for services with inadequate resources (Jayasundara, Danis, Legerski et al., 2018).

The resource-based booms occurring across North America after hydraulic fracturing (fracking) became commonplace after 2005 produced scores of academic papers highlighting the disruptions occurring in boomtowns. Many of these studies examined circumstances in the Bakken region in eastern North Dakota and western Montana, a region that straddles the Manitoba and Saskatchewan borders. Foremost of these challenges was an inability of local governments to meet the demands of their growing populations. Not only did the size of small and rural communities increase, but the composition of the newcomer population-predominantly made up of young, high-salaried males with little stake in the community-leads to increased involvement in antisocial behaviour and crime (Dahle \& Archbold, 2015). Police officers reported many of these newcomers had prior criminal records (Archbold, Dahle, \& Jordan, 2014), and researchers found that the proportion of registered sex offenders living in resource-based boom communities was higher than in neighbouring jurisdictions (Berger \& Beckman, 2010; Jayasundara, Heitkamp, Mayzer et al., 2016a).

Writing about boomtowns, Thomas, Smith, and Ortiz (2016) observed that since the problems associated with a boom can be predicted, they can be prevented. In this paper we propose that a key first step in developing crime prevention strategies in communities experiencing resource-based booms is to consider the life course of these places, and how the evolution of a boom affects community services and public safety. In what follows we briefly define boomtown effects, describe the life course of resource-based boom communities, and discuss the importance of using our knowledge to increase public safety and the quality of life for boomtown residents.

\section{BOOMTOWN EFFECTS}

The outcomes of the rapid population growth and changes associated with resource-based booms have attracted the interest of Canadians since the 1896 Klondike gold rush (Berton, 1972). From the 1900s until today, hundreds of boomtowns emerged throughout rural Canada and although their location, as well as the duration and intensity of each respective boom, may have differed, there are a number of social ills that occur after a boom, which are called boomtown effects. These factors were described by the Government of New Brunswick (2012, p. 5) as:

... impact[ing] community health. These can include increased rates of crime, drug and alcohol abuse, sexually-transmitted infections (STIs), and domestic violence; inadequate supply and equality of housing; increased cost of living; increased community dissatisfaction; increased mental health and social services caseloads; increased hospital admissions; insufficient infrastructure; and insufficient capacity in public services, including policing, local government, social services, and health care.

Although all of these factors reduce the safety and quality of life for boomtown residents, we focus upon the responses of the justice systems to the increase in antisocial behaviour and crime. Media accounts have portrayed Canadian and US boomtowns as a new "wild west," (Daily Mail, 2013; Ferguson, 2007), and journalists report these towns are plagued with "murder and mayhem" (Nienaber, 2014). A review of the actual crime statistics in these places, however, shows that, while overall levels of crime increase in boom communities, most of these offences are fairly minor and associated with drug offences (Grossman, Humphreys, Khalil et al., 2016; Heitkamp, 2016), common assaults, driving under the influence, and 
mischief (Montana Board of Crime Control, 2016; O'Connor, 2017). Those crime increases are fairly consistent in studies carried out in Australia (Carrington, Hogg, \& McIntosh, 2011), Canada (Ruddell, 2011), and the US (Ruddell, 2017).

With respect to serious and violent crimes, a review of the extant research shows an increase in these offences in US jurisdictions after booms occur (James \& Smith, 2017; Liao, Berzofsky, Heller at al., 2015). There is, however, some variation in the distribution of violent offences and there are significantly higher rates of these crimes in some towns or counties (O'Connor, 2017; Ruddell, Jayasundara, Mayzer at al., 2014). Moreover, rates of violent crime tend to decrease over time. With respect to Fort McMurray, for example, Statistics Canada (2018) data shows that the violent crime rate in Fort McMurray was twice the Alberta rate in 1998, but by 2017 Fort McMurray's violent crime rate had decreased by 42 per cent.

The literature supports that some boomtown populations may be more vulnerable to victimization. A growing number of researchers report that violence toward women increases after the start of a boom (James \& Smith, 2017; Jayasundara et al., 2016a; Komarek, 2018). Survivors of family violence may be reluctant to report their victimization to the police if they come from marginalized populations, such as Indigenous women or newcomers who are socially isolated (e.g., unemployed women with few friends or kinship networks). A study of women in rural British Columbia communities that had economies based on resource extraction found that many of them lived in precarious living arrangements, and "were just one argument with their spouse from being on the streets" (Amnesty International Canada, 2016, p. 45). This vulnerability increased in the North Dakota oilfields due to a lack of domestic violence services and shortcomings in the local justice systems that made it difficult to prosecute domestic violence offenders (Ruddell, Britto, \& Schafer, 2018)

The occurrence of dangerous driving is also shown to rise in boomtowns. Fatalities and serious injuries increase as few rural roads were designed for the increased volume of traffic caused by the boom, and local governments could not afford to repair the damages to the roadways caused by large trucks (Raimi \& Newell, 2016). Driving-related offences in boomtowns are also associated with increases in fatal collisions and in Fort McMurray, between 2008 and 2015, 6.4\% of drivers in fatal vehicle crashes had been drinking, were impaired by alcohol or drugs, were fatigued/fell asleep, or reported other medical-related causes, and 13 per cent were travelling at an unsafe speed (Alberta Transportation, 2017). These statistics are indicative of a culture where the end of a worker's shift is synonymous with the desire to abuse alcohol and drugs - what the workers call "blowing off steam" (Amnesty International Canada, 2016).

In addition to the rise in collisions, traffic congestion is also described as reducing a community's quality of life (Anderson \& Theodori, 2009). Britto's (2016) examination of surveys of Fort McMurray residents found that speeding, aggressive driving, and driving under the influence offences were their biggest concerns, with enforcement of these crimes being the top priorities identified for law enforcement to address. In terms of the prevalence of these offences, a review of impaired and dangerous driving offences reveals that these crimes in Fort McMurray in 2017 were about one-fifth higher than the provincial rates (Statistics Canada, 2018).
The increases in antisocial behaviour, crime, and the need for expanded traffic enforcement in these rapid-growth communities place significant burdens on police officer workloads (Archbold et al., 2014, Montana All Threat Intelligence Center and North Dakota State \& Local Intelligence Center, 2012). Officer workloads in Fort McMurray, for example, grew to three times the national average, and it took more than a decade until they decreased to the provincial average (Ruddell, 2011). Local courts are also impacted by the boom and the dockets in oil-impacted counties increased to the point where some cases were backlogged for years (North Dakota Court System, 2015; Perry, 2007). Local probation agencies were also overwhelmed (Guldborg, 2016) and many counties impacted by the boom were forced to expand their jail populations (Ruddell, 2017).

Altogether, we find that levels of antisocial behaviour, disorder, and crimes in boomtown increase, and this places significant demands on the operations of the police, courts, and corrections. It has long been recognized, however, that all social problems occurring in rapid growth communities are in fact interrelated (Gilmore, 1976). This can result in "overwhelmed public services, degradation of quality-of-life factors" and challenges in community planning and development (Bangsud \& Hodur, 2014, p. 43). Jayasundara, Heitkamp and Ruddell (2016b) found the volume of clients seeking help from health, educational, and social service agencies increased after the oil boom occurred in the Bakken, and the cases that workers confronted were more often more serious and complex than ones they had normally encountered. These demands can seem relentless to human service workers, and a respondent in the research by Flanagan, Heitkamp, Nedegaard et al., (2014, p. 100) "described oil booms as a human tornado."

\section{LIFE COURSE PERSPECTIVE}

Local government officials can mitigate boomtown effects by basing their responses to rapid community change on a full understanding of the dynamics occurring in these places. One way to analyze these conditions is to draw upon the life course perspective, which has long been used in the study of human development, and more recently been applied to organizational performance (Aldrich \& Ruef, 2006). The life course perspective is based on understanding the influences of time and history of a boom community, and we argue this approach provides a way of understanding the birth, evolution, and demise of a boom; all booms ultimately bust.

The life course approach presented in this section is modeled on King's (2009) studies of police organizations. The profile was developed following an extensive review of the extant literature and applying a framework analysis to identify the themes reported below. These boomtown effects focus primarily on issues related to crime and the operations of the justice system, and are presented in the following list.

\section{LIFE COURSE OF A RESOURCE-BASED BOOM COMMUNITY}

Rising commodity values increase resource exploration and extraction in rural and/or remote communities. 
The population increases rapidly with the majority of newcomers being young males with little stake in the community. There is an out-migration of established community residents, such as senior citizens. Existing sex ratios are disrupted and men often outnumber women.

- There are an increased number of public order offences (e.g., alcohol-related crimes, drug offences, driving under the influence, and prostitution).

- Incidents of domestic violence increase, as do rates of property crime and non-lethal violence, although the magnitude of the increase varies with location.

- Traffic congestion and the number of serious and fatal collisions increases.

- The population exceeds the community's ability to meet the demand for basic services such as housing. Man camps, with hundreds or thousands of residents, emerge in the areas surrounding the boom's epicenter.

- Demands for health, educational, social, and protective services such as police, fire, and emergency medical services, increase exponentially.

- Quality of life and community well-being decreases with a rise in traffic collisions, pollution, noise, and industrial accidents. Visible signs of disorder, such as litter and graffiti increase.

- Local residents express frustration toward the newcomers and tensions between these groups rises.

- Tension between different factions of long-term community residents can also increase due to conflicts about the desirability and impacts of growth and development. 1. The police struggle to manage the demands created by the growing populations and associated crime rates. Organized crime offenders and gang members supply residents with drugs and are involved in the sex-trade, including sex trafficking. The threshold for arrests increases as officers prioritize responses to serious offences.

- The population composition changes as the construction phase of development ends and the production phase requires fewer employees. Workers with families replace young single males in the population.

Local government services eventually match demands in a sustained boom.

- As the turnover of short-term workers decreases, the population stabilizes, including the ratio of men to women. Crime and disorder plateaus and then drops.

- Resident quality of life and overall community wellbeing improves.

- The economic boom withers and then busts. All resourcebased booms eventually bust.

- Some communities experience cycles of booms and busts as commodity prices and extraction costs fluctuate.

Having profiled the life course of a resource-based boom community, there are a number of limitations regarding the profile portrayed above that should be considered. Jacquet and Kay (2014), for example, point out there is no single type of boomtown and Keough (2015, p. 1189) observes "there is no single contemporary model" for growth. Moreover, not all boomtowns will follow the model presented above, and it is impossible to predict the time span for each of these stages. Boomtown populations increase rapidly; Keough $(2015$, p. 1180) notes that the work camp population of Fort McMurray grew 68 per cent between 2010 and 2012. With respect to the municipal population, Fort McMurray experienced a 120 per cent increase between 2001 and 2016 (Alberta Transportation, 2017).

Whether a boom progresses as presented in this framework is also related to a number of geographical, political, economic, historical, and demographic factors. For example, the expansion of diamond mining in a geographically remote and sparsely populated northern Indigenous community with little economic development will have a different impact compared to a boom based on oil and gas extraction in a rural community 100 kilometres from an urban centre. With respect to geography, fracking can occur across an entire region, and the population increase may be diffused across a number of communities rather than overwhelming a single city, such as the communities of Williston, North Dakota or Fort McMurray (Jayasundara et al., 2016a). Moreover, historical factors, such as whether a community has previously experienced a boom - and whether local government leaders had learned from these lessons of the past-may also play a role in how they manage the boomtown effects. Leaders who have learned from the mistakes of others may also be more successful in mitigating the boomtown effects.

\section{DISCUSSION}

Freudenburg (1981) observes that residents of rural communities anticipating booms are often enthusiastic about the potential for economic growth and reduced unemployment. After experiencing the realities of the boom, however, they quickly become disillusioned with changes affecting their former way of life. Conflict about the desirability of the boom often emerges according to one's status as a "have" (e.g., those benefiting directly from the boom, such as landowners receiving resource royalties) and the "have nots" who have not shared in the benefits of the boom (Jaquet, 2014). Although some long-term residents decide to leave, most do stay and adapt to their new communities and living situations. Other communities may undergo a series of booms, busts, and periods of recovery (Putz, Finken, \& Goreham, 2011), and some Alberta and North Dakota boomtowns experienced at least three of these cycles since the 1950s.

One of the most important steps municipal and county (or regional municipalities) government officials can take is to acknowledge that all booms will end, and that their role is to "protect the public and natural resources, nurture a healthy local business environment, and provide independent oversight of the impacts of...development within their jurisdiction" (Kelsey, Partridge, \& White, 2016, p. 209). Forward-looking politicians and government officials planning for the bust will have ideally channelled surplus revenues into the creation of their municipality's or county's physical infrastructure or human resource development to create long-term advantages for their communities (Kelsey, Partridge, \& White, 2016). That is a tall order, as the evidence shows that the long-term economic, social, and environmental outcomes of a boom are often grim, and many communities are worse off after the boom turns into a bust (Jacobsen \& Parker, 2016). 


\section{CONCLUSIONS}

This commentary started with the contention by Thomas et al. (2016) that, if a social problem can be predicted, it can be prevented. In this paper we describe the life course of resource-based booms and our intent in developing this framework is to provide local government officials a starting point from which to base responses to the rapid population growth and industrialization affecting their communities. Government officials anticipating a boom in their communities or surrounding locales are at some advantage if they can learn from the experiences of others.

\section{CONFLICT OF INTEREST DISCLOSURES}

The authors declare there are no conflicts of interest.

\section{AUTHOR AFFILIATIONS}

*Justice Studies, University of Regina, Regina, SK; ${ }^{+}$Department of Health \& Physical Education, Mount Royal University, Calgary, $\mathrm{AB}$, Canada.

\section{REFERENCES}

Alberta Transportation. (2017). Alberta collision information system. Unpublished raw data.

Aldrich, H. E., \& Ruef, M. (2006). Organizations evolving, $2^{\text {nd }}$ edition. Thousand Oaks, CA: Sage Publications.

Amnesty International Canada. (2016). Out of sight, out of mind: Gender, Indigenous rights, and energy development in northeast British Columbia, Canada. Ottawa, ON: Author.

Anderson, B. J., \& Theodori, G. L. (2009). Local leaders' perceptions of energy development in the Barnett shale. Southern Rural Sociology, 24 113-129.

Archbold, C. A., Dahle, T., \& Jordan, R. (2014). Policing "The Patch": Police response to rapid population growth in oil boomtowns in western North Dakota. Police Quarterly, 17, 386-413.

Bangsud, D. A., \& Hodur, N. M. (2014). Socio-economic effects of oil and gas industry in North Dakota 2014 to 2019. Fargo, ND: North Dakota State University.

Berger, J., \& Beckmann, J. P. (2010). Sexual predators, energy development, and conservation in greater Yellowstone. Conservation Biology, 24 $891-896$.

Berton, P. (1972). Klondike: The last great gold rush, 1896-1899. Toronto: Random House.

Britto, S. (2016). Finding the town amidst the boom: Public perceptions of safety and police priorities in a boomtown milieu. Internet Journal of Criminology, Special issue on boomtowns 2016, 9-26.

Broadway, M. (2007). Meatpacking and the transformation of rural communities: A comparison of Brooks, Alberta and Garden City, Kansas. Rura Sociology, 72, 560-582.

Carrington, K., Hogg, R., \& Mclntosh, A. (2011). The resource boom's underbelly: Criminological impacts of mining development. Australian \& New Zealand Journal of Criminology, 44, 335-354.

Daily Mail. (2013, July 29). Welcome to the new Wild West: Inside the once sleepy North Dakota backwater that has become a new boomtown - and a den of iniquity — with the explosion of oil drilling. Retrieved from https:// www.dailymail.co.uk/news/article-2381141/Williston-North-Dakotaoil-mining-transformed-face-sleepy-backwater-single-men-dramaticallyoutnumber-women.htm

Dahle, T. O., \& Archbold, C. A. (2015). Just do what you can [...]make it work! Exploring the impact of rapid population growth on police organizations in western North Dakota. Policing: An International Journal of Police Strategies \& Management, 38, 805-819.
Ferguson, A. (2007, August 26). In Alberta, cocaine easier to buy than pizza. Edmonton Journal. Retrieved from http://oilsandstruth.org/ alberta-cocaine-easier-buy-pizza

Flanagan, K., Heitkamp, T., Nedegaard, R., \& Jayasundara, D. (2014). Black gold and the dark underside og its development on human service delivery. Contemporary Rural Social Work, 6, 86-106.

Freudenburg, W. R. (1981). Women and men in an energy boomtown: Adjustment, alienation, adaptation. Rural Sociology, 46, 220-244.

Gilmore, J. S. (1976). Boom towns may hinder energy resource development. Science, 191, 535-540

Government of New Brunswick, Department of Health. (2012). Chief Medical Officer of Health's recommendations concerning shale gas development in New Brunswick. Fredericton, NB: Author.

Grossman, D. S., Humphreys, B. R., Khalil, U., \& Ruseski, J. E. (2016). Country roads, take me to heroin? Macroeconomic conditions, drug abuse, and drug substitution in West Virginia. Paper presented at the American Society of Health Economists Biennial Conference, June 12-15, Philadelphia, PA.

Guldborg, A. (2016). Another day in the oil patch: Narratives of probation work in Montana [unpublished MA thesis]. Missoula, MT: University of Montana.

Heitkamp, T. (2016). White paper: Illicit drug use as a context. Unpublished document.

Jacobsen, G. D., \& Parker, D. P. (2016). The economic aftermath of resource booms: Evidence from boomtowns in the American West. The Economic Journal, 126, 1092-1128.

Jacquet, J. B. (2014). Review of risks to communities from shale energy development. Environmental Science \& Technology, 48, 8321-8333.

Jacquet, J. B., \& Kay, D. L. (2014). The unconventional boomtown: Updating the impact model to fit new spatial and temporal scales. Journal of Rural and Community Development, 9, 1-23.

James, A., \& Smith, B. (2017). There will be blood: Crime rates in shale-rich US counties. Journal of Environmental Economics and Management, $84,125-152$

Jayasundara, D., Heitkamp, T., Mayzer, R., Legerski, E., \& Evanson, T. (2016a). Exploratory research on the impact of the growing oil industry in North Dakota and Montana on domestic violence, dating violence, sexual assault, and stalking: a final summary. Grand Forks, ND: University of North Dakota.

Jayasundara, D., Danis, F., Legerski, E., \& Ruddell, R. (2018). Oil development and intimate partner violence: Implementation of Section 8 housing policies in the Bakken region of North Dakota and Montana. Journal of Interpersonal Violence. In press.

Jayasundara, D., Heitkamp, T., \& Ruddell, R. (2016b). Voices from the front line: Human service workers' perceptions of interpersonal violence in resourcebased boom communities. Internet Journal of Criminology Special Issue on Boomtowns 2016, 72-93.

Kelsey, T. W., Partridge, M. D., \& White, N. E. (2016). Unconventional gas and oil development in the United States: Economic experience and policy issues. Applied Economic Perspectives and Policy, 38, 191-214.

Keough, S. B. (2015). Planning for growth in a natural resource boomtown: Challenges for urban planners in Fort McMurray, Alberta. Urban Geography, 36, 1169-1196.

King, W. (2009). Toward a life-course perspective of police organizations. Journal of Research in Crime and Delinquency, 46, 213-244.

Komarek, T. M. (2018). Crime and natural resource booms: Evidence from unconventional natural gas production. The Annals of Regional Science, 61, 113-137.

Liao, D., Berzofsky, M., Heller, D., Barrick, K., \& DeMichele, M. (2015). Treatment of missing data in the FBl's national incident based reporting system: A case study in the Bakken region. Presented at the 2015 Joint Statistical Meetings, August 8-13, Seattle, WA. Alexandria, VA: American Statistical Association. 
Montana All Threat Intelligence Center and the North Dakota State \& Local Intelligence Center. (2012). Impact of population growth on law enforcement in the Williston Basin region. Helena, MT: North Dakota State \& Local Intelligence Center.

Montana Board of Crime Control, Statistical Analysis Center. (2016). Crime in Montana 2014-2015 report. Helena, MT: the Centre.

Nienaber, G. (2014, January 24). Murder, mayhem and Mexican mafia stalk the Bakken oil fields. The Huffington Post. Retrieved from http:// www.huffingtonpost.com/georgianne-nienaber/murder-mahem-andmexican-_b_4646552.html

North Dakota Court System. (2015). North Dakota courts annual report, 2014. Bismarck, ND: Author.

O'Connor, C. D. (2017). Oil, crime, and disorder: A methodological examination of the oil boom's impact in North Dakota. Deviant Behavior, 38 477-491.

Perry, J. R., (2007). The effect of energy development on the courts. Wyoming Law Review, 7, 321-329.

Putz, A., Finken, A., \& Goreham, G. A. (2011). Sustainability in natural resourcedependent regions that experienced boom-bust-recovery cycles: Lessons from a review of the literature. Fargo, ND: North Dakota State University.

Raimi, D., \& Newell, R. G. (2016). Local fiscal effects of oil and gas development in eight states. Durham, NC: Duke University Energy Initiative. Retrieved from https://energy.duke.edu/sites/default/files/ attachments/2a.\%20Local\%20fiscal\%20 effects\%20 of\%20oil\%20 and\%20gas\%20development\%20in\%20eight\%20states\%2OFINAL.pdf
Ruddell, R. (2011). Boomtown policing: Responding to the dark side of resource development. Policing: A Journal of Policy and Practice, 5, 328-342.

Ruddell, R. (2017). Oil, gas, and crime: The dark side of the boomtown. New York: Palgrave Macmillan.

Ruddell, R., Jayasundara, D., Mayzer, R., \& Heitkamp, T. (2014). Drilling down: An examination of the boom-crime relationship in resource-based boom communities. Western Criminology Review, 15, 3-17.

Ruddell, R., Britto, S., \& Schafer, V. (2018). The perfect storm: Family violence in the Bakken oilfields. To be presented at the Resolve Conference, University of Regina, Regina, SK, October 18-19, 2018. Forthcoming.

Statistics Canada. (2018). Incident-based crime statistics, by detailed violations and police services, Alberta. Ottawa, ON: Statistics Canada. Retrieved from https://wwwl50.statcan.gc.ca/tl/tbll/en/ tv. action?pid $=3510018301$

Thomas, M. O., Smith, S. M., \& Ortiz, N. R. (2016). The boom's echo: Learning how to mitigate boomtown effects. Internet Journal of Criminology Special Issue on Boomtowns 2016, 125-138. 